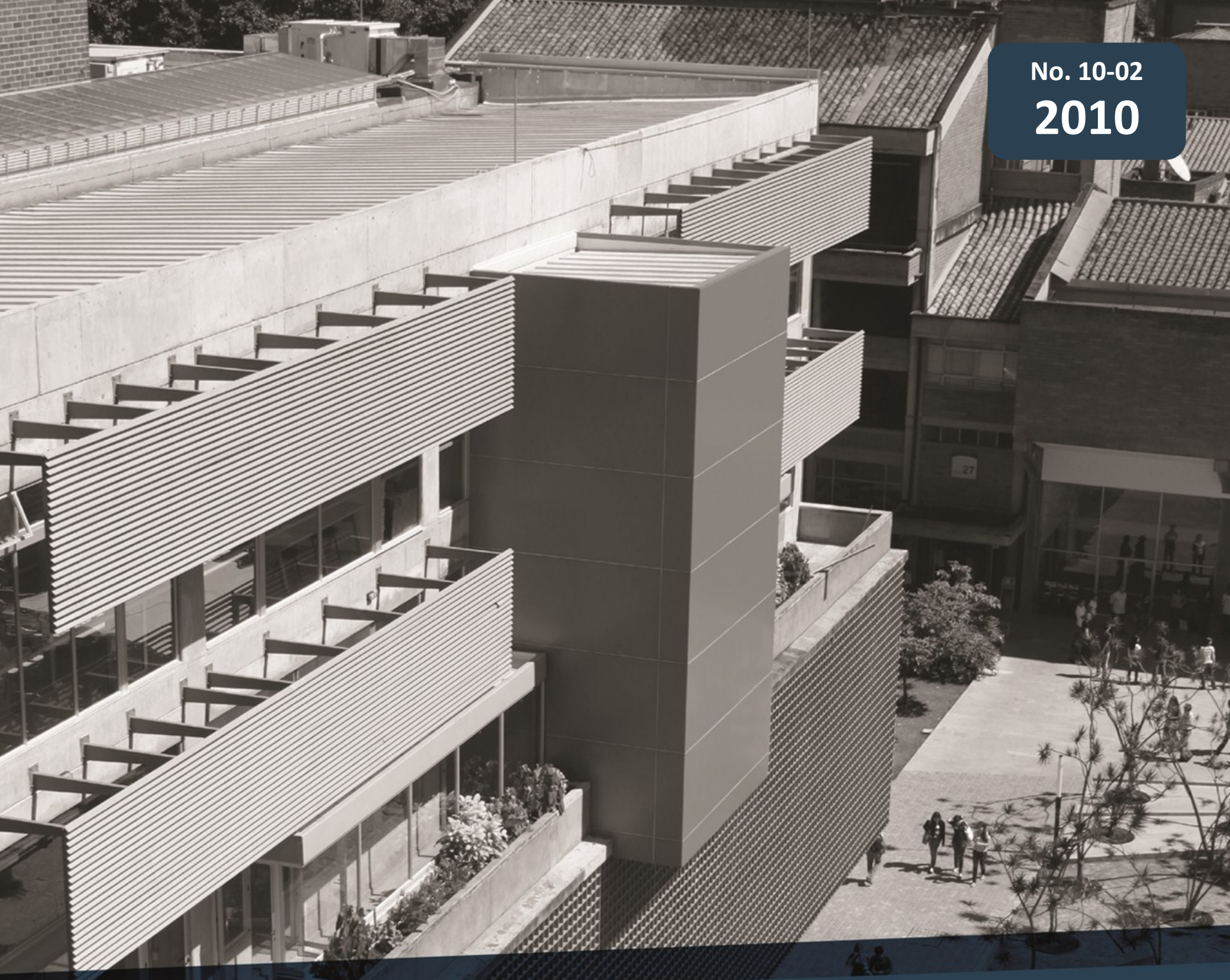

SCHOOLING AND NATIONAL INCOME: HOW LARGE ARE THE EXTERNALITIES? REVISED ESTIMATES.

Theodore Breton

Documentos de trabajo Economía y Finanzas

Centro de Investigaciones Económicas y Financieras (CIEF) 


\title{
Schooling and National Income: How Large Are the Externalities? Revised Estimates
}

\author{
Theodore R. Breton \\ (ted.breton@gmail.com)
}

\section{August 18, 2010}

\begin{abstract}
This article presents revised estimates of the external rates of return on investment in schooling provided in "Schooling and National Income: How Large Are the Externalities?" The analysis is based on data for the same set of countries, but it incorporates methodological improvements that yield lower estimates of these rates. The revised marginal external rates of return range from four percent in the highest-income countries to about 35 percent in the lowest-income countries. These rates are about half the private rates of return in high-income countries and about double the private rates in the lowest-income countries.
\end{abstract}

JEL Codes: E13, I21, O11, O15, O41

Key Words: Human Capital, Education, Schooling, Economic Growth, External Benefits 
In the article "Schooling and National Income: How Large are the Externalities?" Breton [2010] calculates the external benefits of schooling by subtracting estimates of the private rates of return on investment in schooling from estimates of the national rates of return for 20 countries. The national rate of return was calculated from a cross-country estimate of a standard Cobb-Douglas national income model that included a variable for human capital from schooling (Hs):

$$
\mathrm{Y}_{\mathrm{it}}=\mathrm{K}_{\mathrm{it}}^{\alpha} \mathrm{Hs}_{\mathrm{it}}{ }^{\beta}\left(\mathrm{A}_{\mathrm{it}} \mathrm{L}_{\mathrm{it}}\right)^{1-\alpha-\beta}
$$

In that article the marginal product of schooling is specified incorrectly as the change in the level of national income due to the sum of the direct and the indirect effects of changes in schooling on national income:

$$
\mathrm{MPHs}_{\mathrm{it}}=\mathrm{dY}_{\mathrm{it}} / \mathrm{dHs}_{\mathrm{it}}=\beta(\mathrm{Y} / \mathrm{Hs})_{\mathrm{it}}+\left[\alpha(\mathrm{Y} / \mathrm{K})_{\mathrm{it}} *(\delta \mathrm{K} / \delta \mathrm{Hs})_{\mathrm{it}}\right]
$$

Since the marginal product is a partial derivative, which holds the physical capital factor of production $(\mathrm{K})$ constant, the correct equation for the marginal product of schooling includes only the direct effect of schooling on national income: ${ }^{1}$

$$
\mathrm{MPHs}_{\mathrm{it}}=\delta \mathrm{Y}_{\mathrm{it}} / \delta \mathrm{H}_{\mathrm{it}}=\beta(\mathrm{Y} / \mathrm{Hs})_{\mathrm{it}}
$$

As a result of this error, both the national marginal products of schooling and the national marginal external rate of return from investment in are substantially overestimated.

This article presents revised estimates of the private, national, and external marginal rates of return from investment in schooling in 1990. These estimates are calculated using the correct marginal product of human capital from schooling shown in equation (3) and the following methodological improvements:

\footnotetext{
${ }^{1}$ Thanks to Roger Rogerson, who identified the error in the equation for the marginal product of schooling.
} 
- The stock of human capital from schooling $(\mathrm{Hs})$ in 61 countries is estimated as the net stock using the perpetual inventory method rather than as cumulative investment in schooling.

- The foregone student earnings used to estimate $\mathrm{Hs}$ are increased from 0.7 to 0.9 times total direct expenditures on schooling, based on a review of numerous additional empirical studies.

- The estimate of national income (Y) in 1990 is increased to account for foregone student earnings, which Kendrick [1976] identified as a missing component in the national accounts.

- The estimates of the national economic variables are based on data from Penn World Table 6.2 instead of 6.1 [Heston, Summers, and Aten, 2006].

- The estimates of the average private rates of return on investment in schooling are revised using data from Cohen and Soto [2007] on the average schooling of the work force at each level of schooling in 1990.

- In the calculation of the external rates of return on investment in schooling, the private rates of return from workers' earning studies are reduced to make them consistent with the lower average experience of national work forces due to the population growth that occurred between 1950 and 1990.

The revised estimates indicate that the marginal external rate of return on investment in schooling in 1990 ranged from about four percent in the highest-income countries to about 35 percent in the lowest-income countries. These estimates are lower than the estimates presented in Breton [2010], but they continue to indicate that investment in schooling has substantial external benefits in countries with widely varying levels of cumulative investment in schooling. 
The paper is organized as follows: Section I presents the estimates of the net stock of human capital from schooling. Section II presents the revised estimates of $\beta$ in the CobbDouglas income model in equation (1) associated with the revised national data on income (Y) and human capital from schooling (Hs). Section III presents the revised private rates of return from workers' earnings studies. Section IV presents the revised estimates of the national external rates of return from investment in schooling. Section V concludes.

\section{Estimation of the Net Schooling Capital Stock}

Calculation of the national marginal rates of return on schooling in equation (3) requires cross-country data on the stock of human capital from schooling. National estimates of this stock are developed using the perpetual inventory method specified in OECD [2001]. The OECD argues that for financial valuation, the appropriate stock of capital is the net capital stock, which includes all of the capital equipment in operation, with a value for this capital that is either a market value, or is calculated using the initial cost of the gross capital stock and an appropriate rate of financial depreciation. In the case of human capital from schooling, this stock is calculated using the aggregate investment made by the nation in formal schooling, which includes all expenditures related to schooling, including the implicit financial carrying costs and students' foregone earnings.

\section{Gross Human Capital Stock}

The methodology used to estimate the gross human capital stock is a modification of the methodology used in Breton [2010] to estimate the cumulative investment in schooling in 61 countries. After completion of their schooling, students are presumed to work for 40 years. A country's gross human capital stock from schooling in year $t$ is assumed to be equal to the cumulative national investment in schooling over the years $t-45$ to $t-5$. The five-year lag in the 
period used to estimate the capital stock is a rough approximation of the delay from a presentdiscounted-value standpoint between the time when a nation invests in schooling and the time that a student enters the work force. This lag is less than half the average student's period of schooling because higher levels of schooling have much higher unit costs than lower levels of schooling.

In this revised methodology the cumulative investment is estimated using data on public expenditures as a share of national income, a national ratio of total to public expenditures to account for private expenditures, a 1.9 ratio of total investment to total expenditures to account for foregone earnings, a national ratio of financial carrying costs for schooling investments, and national income:

$$
\text { Gross } \mathrm{Hs}_{\mathrm{it}}=1.9 *(\operatorname{TotExp} / \mathrm{PubExp})_{\mathrm{i}} * 5 * \sum_{j=1}^{8}\left[(\mathrm{PubExp} / \mathrm{Y})_{\mathrm{it}-5 \mathrm{j}} * \mathrm{Y}_{\mathrm{it}-5 \mathrm{j}} * \text { FinCost }_{\mathrm{it}-5 \mathrm{j}}\right]
$$

The data on the ratio of public expenditures to GDP and the ratio of total to public expenditures for the period 1950-1985 are taken from Breton [2010], who obtained or estimated these ratios from UNESCO data. National income, adjusted for purchasing power parity, is obtained from the Penn World Table (PWT) 6.2 data [Heston, Summers, and Aten, 2006].

The lag between the time when the investment in schooling is made and the time when a student enters the work force has a financial cost, which in the case of physical capital is typically denoted "interest during construction," or IDC. This financial cost is included in the estimate of each country's gross human capital stock. It is calculated using an annual cost of capital of 8.0 percent and each country's distribution of schooling attainment in 1990 from Cohen and Soto's [2007] data. The cost of capital is based on Caselli and Feyrer's [2007] finding that the marginal product of reproducible physical capital is very similar across countries, with an average between 6.9 and 8.4 percent. The financial cost factor in equation (4) increases 
the gross capital investment relative to outlays by factors that range from 1.3 to 1.7 across countries, depending on the average length of schooling. These ratios are shown in the Appendix.

\section{Foregone Student Earnings}

The 0.9 ratio of foregone earnings to total national expenditures on schooling was estimated based on a review of data in nine countries, principally for the late 1960s. This time period is the mid-point of the period of investment in schooling for the 1990 work force. The data were obtained from several sources. Raw data on direct costs and foregone earnings in the late 1960s by level of schooling were obtained for nine countries from Psacharopoulos [1973]. These data were weighted using the 1970 distribution of schooling by level provided in Cohen and Soto [2007] and an assumed schooling duration of six years for primary and secondary schooling and four years for university. The resulting estimates of the ratio of foregone earnings to direct expenditures are shown in Table 1. These estimates range from 0.23 in Malaysia to 1.54 in Great Britain. The average ratio was 1.02 .

A review of Psacharopoulos's notes on the foregone earnings data in his study indicated that in some countries these earnings are not representative of all workers. In the U.S. the data are for white males only. In Great Britain foregone earnings at the university level are for science and engineering students. In Colombia workers were assumed to work full-time for 50 weeks, with no period of unemployment. These assumptions are likely to lead to an overestimate of foregone earnings under actual working conditions in these three countries.

Data from two other more comprehensive studies of national investment in schooling also indicate that the estimates in Table 1 are too high. Tilak [1988] provides estimates of the ratio of foregone earnings in India in 1979-80. The upper bound on his ratio of foregone earnings to 
expenditures on schooling was 0.72 . He also provides Kothari's estimates of the ratio of foregone earnings to direct expenditures in India for 1960, which averaged 0.99. Both of these estimates are considerably below the ratio of 1.12 percent for India calculated from the data in Psacharopoulos [1973]. The average ratio for the two comprehensive studies in India is 0.86 .

\begin{tabular}{|l|c|c|c|}
\hline \multicolumn{4}{|c|}{ Table 1 } \\
\hline & Estimated* & Tilak [1988] & Kendrick [1976] \\
\hline Chile & 0.69 & & \\
\hline Colombia & 0.79 & & \\
\hline India & 1.12 & 0.86 & \\
\hline South Korea & 1.27 & & \\
\hline Malaysia & 0.23 & & \\
\hline Mexico & 1.53 & & \\
\hline Great Britain & 1.54 & & 0.90 \\
\hline New Zealand & 1.03 & & \\
\hline United States & 0.99 & & \\
\hline Average & $\mathbf{1 . 0 2}$ & & \\
\hline *Estimated from data on direct costs and foregone earnings in Psacharopoulos [1973]. \\
\hline
\end{tabular}

Kendrick [1976] estimated the total capital investment in the U.S. in 1969. He estimated that the ratio of foregone earnings to direct expenditures was 0.90 . This estimate also is below the ratio of 0.99 for the U.S. calculated from the data in Psacharopoulos [1973].

The review of the assumptions for the foregone earnings estimates in Psacharopoulos's data indicates that the average ratio in these nine countries is below 1.02. The average ratio of foregone earnings to direct expenditures in the two comprehensive studies is 0.88 . There is no evidence in these studies that the ratio of foregone earnings to direct expenditures varies across national income levels. Based on this review of the data in these studies, foregone earnings are estimated to be 90 percent of total direct expenditures in all countries.

\section{Human Capital Depreciation}


The net human capital stock from schooling (Hs) is estimated by applying a financial depreciation rate to the gross human capital stock. The OECD [2001] recommends that financial depreciation be estimated based on the market value of the capital stock over the capital's useful life. Since human capital does not have a market value, the implied value must be estimated based on the present discounted value of human capital's expected future income stream.

By assuming that human capital's contribution to national income over its life is proportional to its contribution to workers' earnings, worker earnings patterns by level of schooling can be used to determine an appropriate depreciation rate. Figure 1 shows the average of the earnings patterns for workers with four levels of schooling in Ecuador, Paraguay, Uruguay, and the Philippines around $1990 .^{2}$ This pattern is typical of patterns in every market economy, in that workers' earnings rise over time at all levels of schooling.

An analysis of the present discounted value of the increase in workers' earnings due to schooling indicates that a linear financial depreciation pattern is consistent with the implied market value of human capital from schooling over a worker's life. An annual depreciation rate of 2.5 percent was applied to the gross human capital stock to calculate the net capital stock in 1990. The data for the net human capital stocks in 1990 for the 61 countries are provided in the Appendix.

\section{Estimation of the Macro Rates of Return}

The income model in equation (1) is estimated as a model of income per worker to reduce potential heterogeneity bias:

$$
(\mathrm{Y} / \mathrm{L})_{\mathrm{it}}=(\mathrm{K} / \mathrm{L})_{\mathrm{it}}{ }^{\alpha}(\mathrm{Hs} / \mathrm{L})_{\mathrm{it}}{ }^{\beta} \mathrm{A}_{\mathrm{it}}
$$

\footnotetext{
${ }^{2}$ The earnings data for these four countries were obtained from Gomez-Castellanos and Psacharopoulos [1990], Psacharopoulos, Velez, and Patrinos [1994], Psacharopoulos and Velez [1994], and Hossain and Psacharopoulos [1994].
} 
A dummy variable for the sub-Saharan African countries is included to control for the reduced productivity (A) of the work force due to the high morbidity and mortality rates in these countries.

Figure 1: Typical Worker's Earnings vs. Experience by Level of Schooling

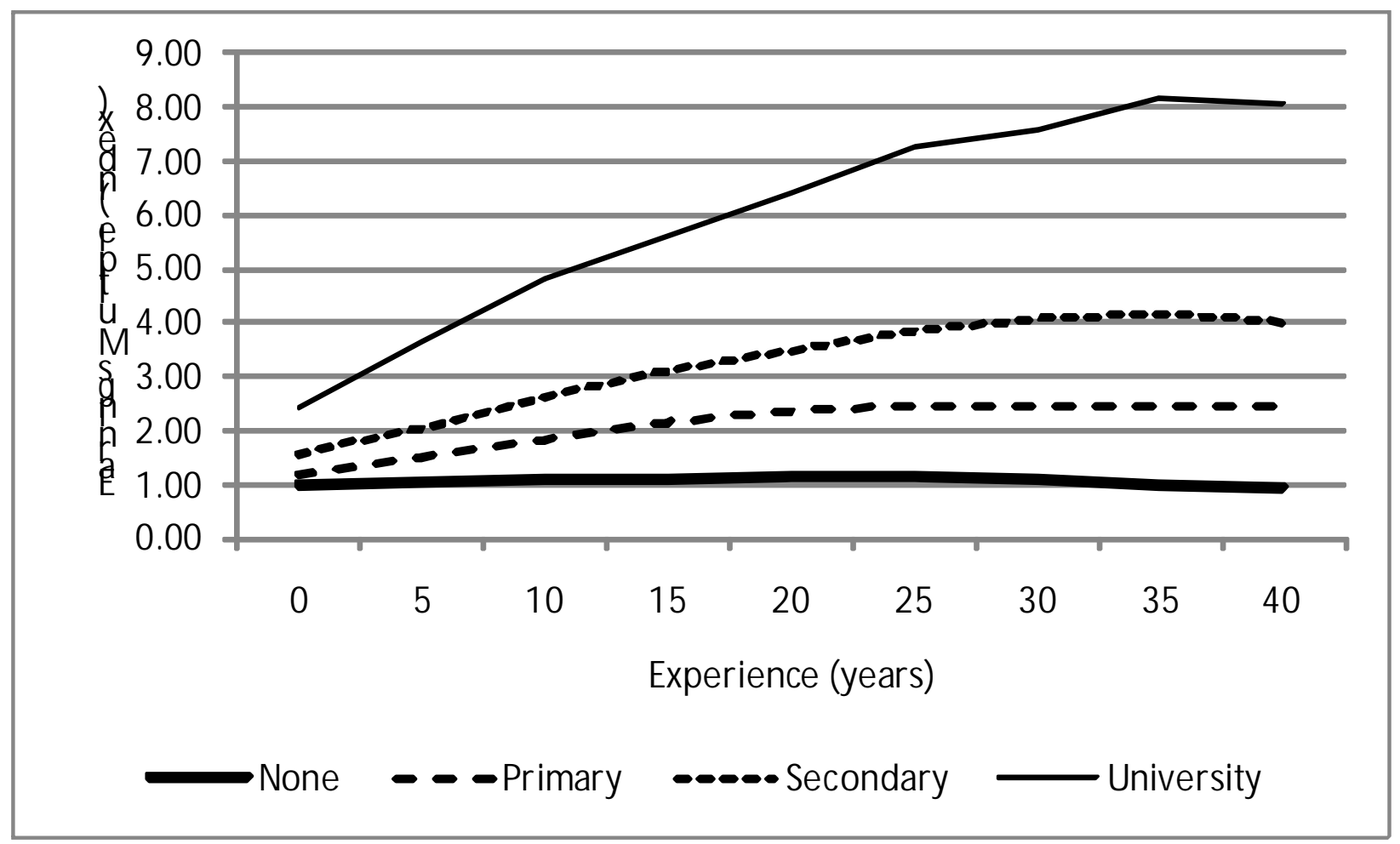

In the estimation of the income model, income per adult, human capital from schooling per adult, and physical capital per adult are used for $\mathrm{Y} / \mathrm{L}, \mathrm{Hs} / \mathrm{L}$, and $\mathrm{K} / \mathrm{L}$. The total investment in physical capital per adult during 1975-89 (the prior 15 years) in the PWT 6.2 data is used as a proxy for the physical capital stock in each country. As the model is estimated in log form, this proxy does not bias the results if it is proportional to the true (net) physical capital stock. National income per adult is estimated from the PWT 6.2 data, augmented by the foregone earnings of students in 1990, which are calculated using the methodology described earlier. 
Human capital from schooling is calculated from the investment occurring 45 to five years earlier, so in the estimate of the national income model, the human capital stock is predetermined. Nevertheless, across countries there could be reverse causality between the stock of human capital and national income, so an instrumental variable is needed to control for simultaneity bias. Breton [2010] uses the log of the Protestant share of the population twenty years earlier as an instrument for cumulative national investment in schooling. This same instrument is used for net human capital from schooling in the 2SLS regressions in this analysis. The data on the Protestant share are obtained from Barrett [1982].

The regression results for the log version of the income model in equation (5) are shown in Table 1. Column 1 shows the results for an OLS regression. The estimate of $\alpha$ in this regression (0.38) is consistent with independent estimates of the share of national income accruing to physical capital, as required in a valid Cobb-Douglas model of a national economy. Bernanke and Gurkaynak [2001] have estimated that physical capital's share of national income is about 35 percent across countries. The estimate of $\beta=0.31$ is higher than estimates obtained in earlier studies, due in part to the higher estimates of national income in the data base resulting from the addition of students' foregone earnings to the Penn World Table data. The coefficients on the capital variables are highly statistically significant, and the model accounts for 95 percent of the variation in $\log (\mathrm{Y} / \mathrm{L})$ across the 61 countries.

Column 2 presents the OLS estimates of the model with the addition of the Protestant share variable to investigate whether there is any indication that this characteristic affects national income directly. The direct effect of the Protestant share on national income is negligible, the coefficients on the physical capital and human capital are virtually unchanged, and the variation in national income explained by the model is unchanged. There is no 
indication that the Protestant share of the population affects income other than through its effect on the level of schooling. ${ }^{3}$

\begin{tabular}{|c|c|c|c|c|}
\hline \multicolumn{5}{|c|}{$\begin{array}{c}\text { Table 1 } \\
\text { Effect of Human Capital from Schooling on National Income } \\
\text { [Dependent Variable is } \log (\text { National Income/Adult })]\end{array}$} \\
\hline & 1 & 2 & 3 & 4 \\
\hline Technique & OLS & OLS & $2 \mathrm{SLS}$ & OLS \\
\hline Countries & 61 & 61 & 61 & 61 \\
\hline $\log (\mathrm{K} / \mathrm{L})$ & $\begin{array}{l}0.38^{*} \\
(.06)\end{array}$ & $\begin{array}{c}0.38^{*} \\
(.06)\end{array}$ & $\begin{array}{l}0.35 \\
(.14)\end{array}$ & $\begin{array}{l}0.34 \\
(.14)\end{array}$ \\
\hline $\log (\mathrm{Hs} / \mathrm{L})$ & $\begin{array}{c}0.31^{*} \\
(.06)\end{array}$ & $\begin{array}{l}0.32 * \\
(.06)\end{array}$ & $\begin{array}{l}0.34 \\
(.14)\end{array}$ & $\begin{array}{c}0.30^{*} \\
(.06)\end{array}$ \\
\hline Est $\log (\mathrm{Hs} / \mathrm{L})$ & & & & $\begin{array}{l}0.05 \\
(.16) \\
\end{array}$ \\
\hline Sub-Saharan Africa & $\begin{array}{c}-0.27 \\
(.11)\end{array}$ & $\begin{array}{c}-0.26 \\
(.11)\end{array}$ & $\begin{array}{c}-0.28 \\
(.11)\end{array}$ & $\begin{array}{c}-0.28^{*} \\
(.11)\end{array}$ \\
\hline $\log ($ Protestant Share $)$ & & $\begin{array}{c}-0.04 \\
(.07)\end{array}$ & & \\
\hline 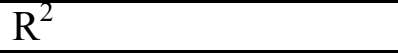 & .95 & .95 & .95 & .95 \\
\hline
\end{tabular}

Column 3 presents the 2SLS estimate of the model using the $\log$ (Protestant share) instrument. The coefficients on physical capital and human capital are similar to the OLS estimate, indicating that the OLS estimates of the coefficients are unbiased. The results from the first stage of the 2SLS estimate indicate that the Protestant share variable is a valid instrument for human capital from schooling:

$$
\log (\mathrm{Hs} / \mathrm{L})=0.79 \log (\mathrm{K} / \mathrm{L})+0.10 \log (\text { Prot Share })-0.17 \text { SSAfrica }+1.98 \quad \mathrm{R}^{2}=.85
$$

\footnotetext{
${ }^{3}$ Becker and Woessmann [2009] present evidence that Protestants' higher rate of literacy entirely explains their higher income relative to Catholics in Prussia in 1871, so again there is no evidence that Protestant affiliation affects national income through mechanisms other than its effect on the incidence of schooling.
} 
The Hausman test in column 4 confirms that the small difference between the OLS and 2SLS estimates of $\beta$ is not statistically significant. Even though this tests indicate that the OLS estimate of $\beta=0.31$ is unbiased, the 2SLS estimates of $\alpha=0.35$ and $\beta=0.34$ are preferred due to the existence of the independent evidence that $\alpha=0.35 .^{4}$ For this reason the 2SLS estimate of $\beta$ $=0.34$ is used to calculate the macro returns on investment in schooling in 1990 . This estimate of $\beta$ is substantially higher than the estimate of $\beta=0.27$ in Breton [2010].

The national marginal rates of return on investment in schooling in 1990 calculated using equation (3) are shown in Figure 2 as a function of the net human capital stock. The pattern of rates exhibits substantial diminishing returns as countries increase their cumulative investment in schooling, but the marginal rates remain attractive relative to rates of return on physical capital even in countries with high levels of investment in schooling.

\section{Rates of Return in Workers' Earnings Studies}

Psacharopoulos and Patrinos [2004] summarize the rates of return on investment in schooling from workers' earnings studies performed in numerous countries. They provide "full return" private rates and social rates for all levels of schooling during the period 1985-1996 for 19 of the 61 countries included in the macro data set. ${ }^{5}$ The social rates of return include the public costs of schooling, so they are the most comparable to the rates of return calculated from the macro data. These rates are provided for primary, secondary, and tertiary levels of schooling.

The weighted average national social rates of return for these 19 countries were calculated using the 1990 distribution of schooling attainment by level in Cohen and Soto [2007]

\footnotetext{
${ }^{4}$ Bernanke and Gurkaynak's [2001] did not include students' foregone earnings in the national income data they used to estimate the share of national income accruing to physical capital. If they had included these foregone earnings, their estimate of the share of national income accruing to physical capital would have been slightly smaller.

${ }^{5}$ Breton [2010] included data for Singapore in the data set used to estimate the external rate of return. Singapore is not included in this data set because these data were from a later time period (1998).
} 
and the relative unit costs at each level of schooling for low-income and high-income countries in Breton [2010]. These rates are shown in Table 2. A review of these rates indicates that they exhibit considerable variance by level within countries and at the same level of schooling across countries.

Figure 2: Marginal National Rates of Return on Investment in Schooling in 1990

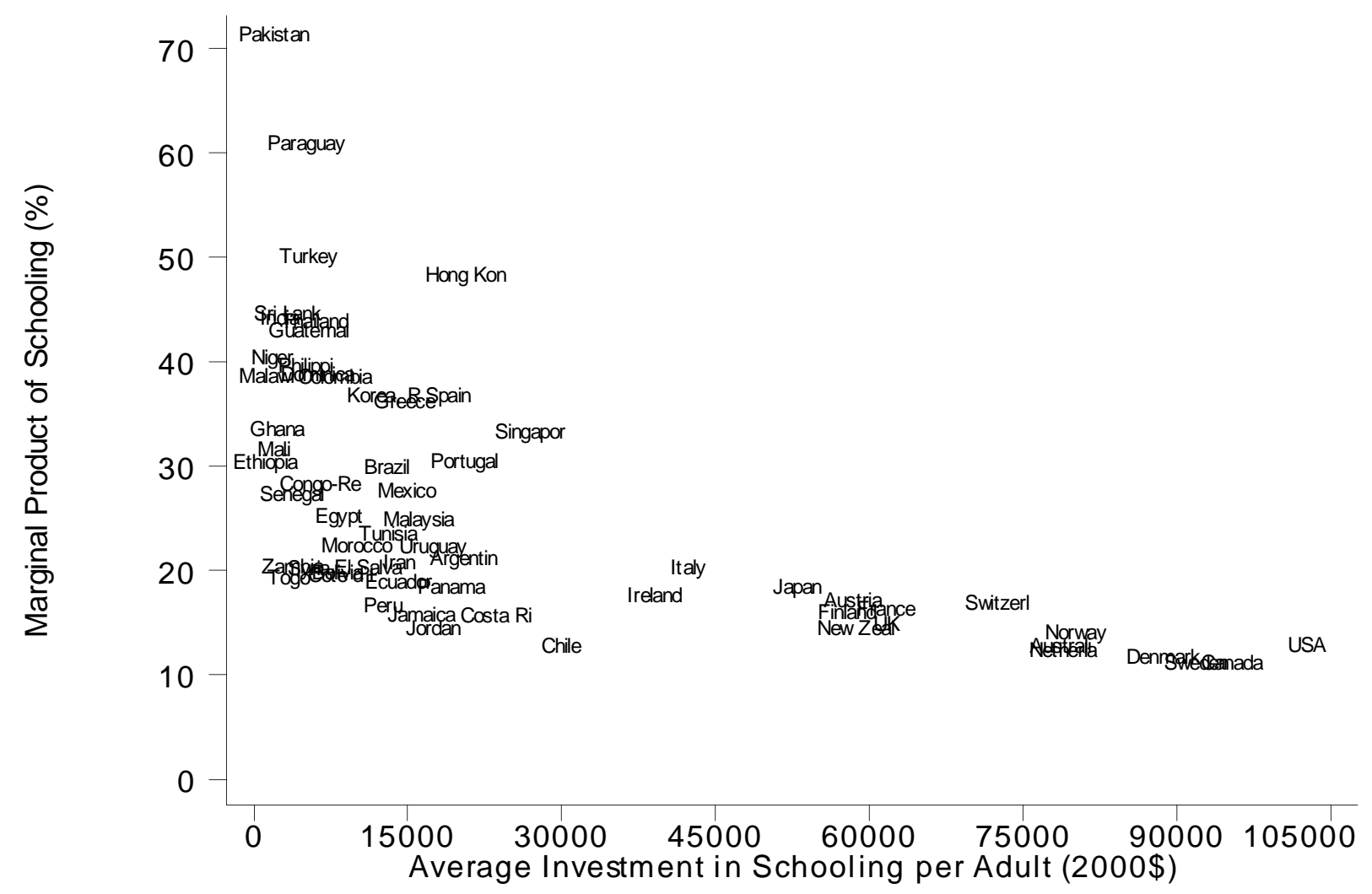

\section{External Rates of Return on Investment in Schooling}

The national rates of return and the private rates of return are not comparable because the workers' level of experience is not the same at the macro and micro levels. Due to the growth in the adult population over the 1950-1990 period, the average worker in each country had less work experience than assumed in the workers' earnings studies. As shown in Figure 1, workers with less experience receive lower incomes, and these lower incomes lead to a lower estimated 
return on investment in human capital from schooling. Without correction this inconsistency in the level of experience between the private (micro) and national (macro) rates of return would bias downward the estimate of the external rate of return from investment in schooling.

\begin{tabular}{|l|c|c|c|c|c|c|c|c|}
\hline \multicolumn{7}{|c|}{ Table 2 } \\
\hline Rates of Return on Investment from Earnings Studies - Full Return Method \\
\hline & Year & \multicolumn{2}{|c|}{ Rate of Return (\%) } & \multicolumn{2}{c|}{ Share of Investment } & Rate (\%) \\
\hline Argentina & 1989 & 8.4 & 7.1 & 7.6 & 0.50 & 0.33 & 0.17 & 7.8 \\
\hline Bolivia & 1990 & 13 & 6.0 & 13.0 & 0.36 & 0.41 & 0.23 & 10.1 \\
\hline Brazil & 1989 & 35.6 & 5.1 & 21.4 & 0.49 & 0.32 & 0.19 & 23.1 \\
\hline Chile & 1993 & 8.1 & 11.1 & 14.0 & 0.41 & 0.44 & 0.15 & 10.3 \\
\hline Colombia & 1989 & 20 & 11.4 & 14.0 & 0.52 & 0.27 & 0.21 & 16.4 \\
\hline Costa Rica & 1989 & 11.2 & 14.4 & 9.0 & 0.44 & 0.20 & 0.36 & 11.0 \\
\hline Ecuador & 1989 & 14.7 & 12.7 & 9.9 & 0.38 & 0.33 & 0.30 & 12.6 \\
\hline El Salvador & 1990 & 16.4 & 13.1 & 8.0 & 0.47 & 0.27 & 0.26 & 13.3 \\
\hline Ethiopia & 1996 & 14.9 & 14.4 & 11.9 & 0.75 & 0.25 & 0.00 & 14.8 \\
\hline Jamaica & 1989 & 17.7 & 7.9 & 7.9 & 0.54 & 0.37 & 0.08 & 13.2 \\
\hline Mexico & 1992 & 11.8 & 14.6 & 11.1 & 0.52 & 0.24 & 0.24 & 12.3 \\
\hline New Zealand & 1991 & $12.4 * *$ & 12.4 & 9.5 & 0.45 & 0.41 & 0.15 & 12.0 \\
\hline Paraguay & 1990 & 20.3 & 12.7 & 10.8 & 0.56 & 0.26 & 0.18 & 16.6 \\
\hline Philippines & 1988 & 13.3 & 8.9 & 10.5 & 0.42 & 0.36 & 0.22 & 11.1 \\
\hline Senegal & 1985 & 23 & 8.9 & 8.9 & 0.52 & 0.36 & 0.12 & 16.2 \\
\hline Spain & 1991 & 7.4 & 8.5 & 13.5 & 0.62 & 0.29 & 0.09 & 8.3 \\
\hline UK & 1986 & 8.6 & 7.5 & 6.5 & 0.40 & 0.49 & 0.10 & 7.8 \\
\hline Uruguay & 1989 & 21.6 & 8.1 & 10.3 & 0.49 & 0.29 & 0.21 & 15.2 \\
\hline USA & 1987 & $10.0 * *$ & 10.0 & 12.0 & 0.37 & 0.43 & 0.20 & 10.4 \\
\hline *Source: Psacharopoulos and Patrinos [2004] & & & & & \\
**Assumed to be the same as the rate at the secondary level. & & & & \\
\hline
\end{tabular}

Table 3 shows the adjustments in the private rates of return made to ensure consistency between the private and national rates and the resulting external rates of return. The private rates of return are reduced to make them consistent with the lower average worker experience implicit in the national rates. The adjustments to the internal private rate of return are approximate, as they are based on the average share of investment at each level of schooling in the 19-country data set and the relationship between worker experience and earnings in Figure 1. As shown, the 
higher the growth rate of the labor force, the larger the reduction in the private rate used in the adjustment for each country. The reduction in the private rate of return ranges from 0.5 to 3.4 percent, with an average reduction of 2.4 percent.

\begin{tabular}{|l|l|c|c|c|c|c|}
\hline \multicolumn{7}{|c|}{$\begin{array}{c}\text { Table 3 } \\
\text { Calculation of Marginal External Rates of Return Adjusted for Experience (\%) }\end{array}$} \\
\hline & $\begin{array}{c}\text { Labor } \\
\text { Growth }\end{array}$ & $\begin{array}{c}\text { Private } \\
\text { Rate }\end{array}$ & $\begin{array}{c}\text { Decline in } \\
\text { Private Rate }\end{array}$ & $\begin{array}{c}\text { Adjusted } \\
\text { Private Rate }\end{array}$ & $\begin{array}{c}\text { Macro } \\
\text { Rate }\end{array}$ & $\begin{array}{c}\text { External } \\
\text { Rate }\end{array}$ \\
\hline Argentina & 1.6 & 7.8 & 2.1 & 5.7 & 20.5 & 14.8 \\
\hline Bolivia & 2.2 & 10.1 & 2.6 & 7.5 & 19.1 & 11.6 \\
\hline Brazil & 2.9 & 23.1 & 3.1 & 20 & 29.3 & 9.3 \\
\hline Chile & 2.2 & 10.3 & 2.6 & 7.7 & 12.1 & 4.4 \\
\hline Colombia & 2.9 & 16.4 & 3.1 & 13.3 & 37.9 & 24.6 \\
\hline Costa Rica & 3.3 & 11.0 & 3.4 & 7.6 & 15 & 7.4 \\
\hline Ecuador & 2.9 & 12.6 & 3.1 & 9.5 & 18.2 & 8.7 \\
\hline El Salvador & 2.5 & 13.3 & 2.8 & 10.5 & 19.7 & 9.2 \\
\hline Ethiopia & 2.1 & 14.8 & 2.5 & 12.3 & 29.8 & 17.5 \\
\hline Jamaica & 1.5 & 13.2 & 1.9 & 11.3 & 15.1 & 3.8 \\
\hline Mexico & 2.9 & 12.3 & 3.1 & 9.2 & 27 & 17.8 \\
\hline New Zealand & 1.7 & 12.0 & 2.1 & 9.9 & 13.8 & 3.9 \\
\hline Paraguay & 2.5 & 16.6 & 2.8 & 13.8 & 60.3 & 46.5 \\
\hline Philippines & 2.9 & 11.1 & 3.1 & 8 & 39 & 31.0 \\
\hline Senegal & 2.5 & 16.2 & 2.8 & 13.4 & 26.7 & 13.3 \\
\hline Spain & 1.1 & 8.3 & 1.5 & 6.8 & 36.1 & 29.3 \\
\hline UK & 0.4 & 7.8 & 0.5 & 7.3 & 14.2 & 6.9 \\
\hline Uruguay & 0.9 & 15.2 & 1.2 & 14 & 21.7 & 7.7 \\
\hline USA & 1.4 & 10.4 & 1.8 & 8.6 & 12.2 & 3.6 \\
\hline
\end{tabular}

The calculated marginal external rates of return in Table 3 range from 3.6 percent in the highest income country (the U.S.) to 46.5 percent in Paraguay. While there could be substantial error in the individual rates due to the measurement error in the various elements of the rate of return estimates, the pattern in the rates is likely to be more accurate than the individual rates. Figure 3 shows the fitted trend for the private rates of return and the external rates of return in the 19-country data set. This trend shows that the external rate of return varies from four percent 
in the countries with the largest stock of human capital to about 35 percent in the countries with the lowest stock of human capital. In proportion to the private rates of return, the external rates vary from about half the private rate of return in countries with high levels of human capital to about double the private rate of return in countries with low levels of human capital.

Figure 3: Marginal Private and External Rates of Return on Investment in Schooling

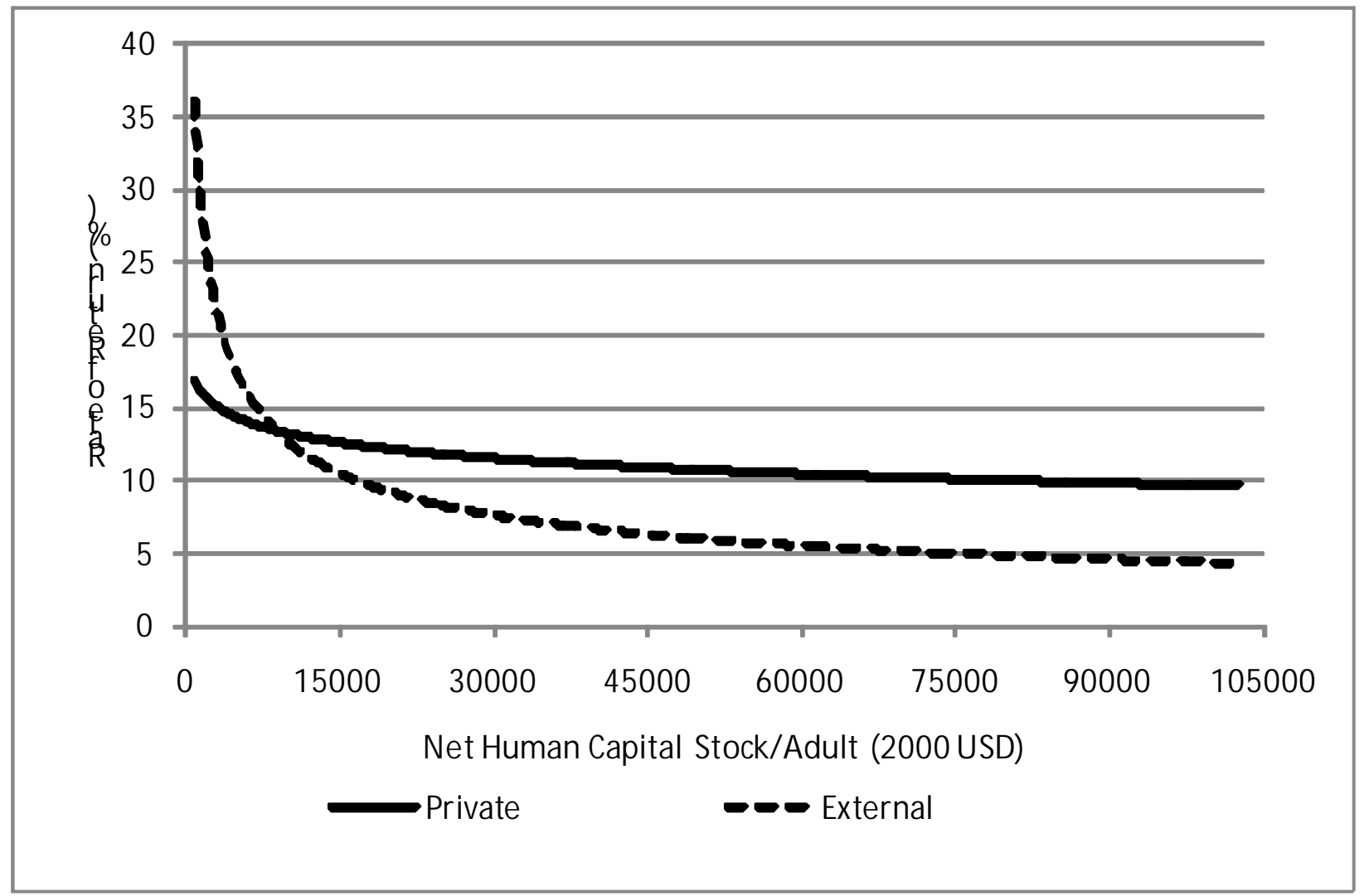

\section{Conclusions}

The external rates of return calculated with the improved methodology have the same pattern as in Breton [2010], but the magnitude of these rates is considerably lower. Nevertheless, the revised rates continue to indicate that national investment in schooling has a positive external effect on national income and that this effect is larger in percentage terms for countries with 
lower levels of human capital from schooling. Implicitly, educated workers have a larger spillover effect on the productivity of other workers in countries where the average level of schooling is lower.

The rates of return estimated in this study are for 1990, so they may not be representative of the marginal return on investment in schooling today. National levels of human capital have increased considerably in the last 20 years, and the trends in Figure 3 clearly show that investment in schooling is subject to diminishing returns. But the rate of decline in these returns was quite slow in 1990 at higher levels of human capital, and in 1990 the total marginal rate of return (private + external) in the highest-income countries was about 14 percent. It seems likely that twenty years later the marginal rate of return on national investment in schooling continues to be higher than the marginal cost of capital. 


\section{REFERENCES}

Barrett, David B., 1982, The World Christian Encyclopedia, Oxford University Press, New York

Becker, Sascha O., and Wössmann, Ludger, 2009, “Was Weber Wrong? A Human capital

Theory of Protestant Economic History," Quarterly Journal of Economics, v124, i2, 531-596

Bernanke, Ben S., and Gurkaynak, Refet S., 2001, “Taking Mankiw, Romer, and Weil

Seriously," NBER Macroeconomics Annual, v16, 11-57

Breton, Theodore R., 2010, "Schooling and National Income: How Large are the

Externalities?," Education Economics, v18, n1, 67-92

Caselli, Francesco, and Feyrer, James, 2007, “The Marginal Product of Capital,” Quarterly

Journal of Economics, v122, n2, 535-568

Cohen, Daniel, and Soto, Marcelo, 2007, “Growth and Human Capital: Good Data, Good

Results," Journal of Economic Growth, v12, n1, 51-76

Gomez-Castellanos, Luisa, and Psacharopoulos, George, 1990, "Earnings and Education in

Ecuador: Evidence from the 1987 Household Survey," Economics of Education Review, v9, n3, 219-227

Heston, Alan, Summers, Robert, and Aten, Bettina, 2006, Penn World Table Version 6.2, Center for International Comparisons of Production, Income and Prices at the University of Pennsylvania (CICUP), September

Hossain, Shaikh I., and Psacharopoulos, George, 1994, “The Profitability of School Investments in an Educationally Advanced Developing Country," International Journal of Educational Development, v14, n1, 35-42

Kendrick, John W., 1976, The Formation and Stocks of Total Capital, National Bureau of Economic Research, New York 
OECD, 2001, "Measuring Capital; OECD Manual: Measurement of Capital Stocks, Consumption of Fixed Capital, and Capital Services," OECD Publication Services, www.SourceOECD.org

Psacharopoulos, George, 1973, Returns to Education: An International Comparison, Jossey-Bass

Inc., Publishers, San Francisco

Psacharopoulos, George and Patrinos, Harry, 2004, "Returns to Investment in Education: A

Further Update," Education Economics, v12, n2, 111-134

Psacharopoulos, George, and Velez, Eduardo, 1994, "Education and the Labor Market in

Uruguay," Economics of Education Review, v13, n1, 19-27

Psacharopoulos, George, Velez, Eduardo, and Patrinos, Harry Anthony, 1994, "Education and

Earnings in Paraguay," Economics of Education Review, v13, n4, 321-327

Tilak, Jandhyala B. G., 1988, “Costs of Education in India," International Journal of

Educational Development, v8, n1, 25-42 


\section{APPENDIX}

\begin{tabular}{|c|c|c|c|c|}
\hline \multicolumn{5}{|c|}{$\begin{array}{c}\text { Table A-1 } \\
\text { Macro Data Used in the Estimation of National Rates of Return }\end{array}$} \\
\hline Country & $\mathbf{Y} / \mathbf{L}$ & Hs/L & Financial Multiple & MPHs \\
\hline & 2000\$/Adult & 2000\$/Adult & Ratio & Percent \\
\hline Argentina & 12305 & 20400 & 1.44 & 20.5 \\
\hline Australia & 27834 & 78567 & 1.68 & 12.0 \\
\hline Austria & 28286 & 58301 & 1.58 & 16.5 \\
\hline Bolivia & 4561 & 8116 & 1.43 & 19.1 \\
\hline Brazil & 11096 & 12885 & 1.40 & 29.3 \\
\hline Canada & 29461 & 95251 & 1.66 & 10.5 \\
\hline Chile & 10622 & 29873 & 1.50 & 12.1 \\
\hline Colombia & 8793 & 7892 & 1.39 & 37.9 \\
\hline Congo-Rep & 5163 & 6357 & 1.30 & 27.6 \\
\hline Costa Rica & 10400 & 23553 & 1.38 & 15.0 \\
\hline Cote d'Ivoire & 4739 & 8535 & 1.31 & 18.9 \\
\hline Denmark & 28730 & 88616 & 1.61 & 11.0 \\
\hline Dominican Rep & 6921 & 6174 & 1.36 & 38.1 \\
\hline Ecuador & 7528 & 14044 & 1.42 & 18.2 \\
\hline Egypt & 6033 & 8343 & 1.36 & 24.6 \\
\hline El Salvador & 6418 & 11102 & 1.35 & 19.7 \\
\hline Ethiopia & 896 & 1022 & 1.30 & 29.8 \\
\hline Finland & 26090 & 57698 & 1.57 & 15.4 \\
\hline France & 28326 & 61517 & 1.55 & 15.7 \\
\hline Ghana & 2143 & 2213 & 1.35 & 32.9 \\
\hline Greece & 15288 & 14625 & 1.48 & 35.5 \\
\hline Guatemala & 6522 & 5237 & 1.34 & 42.3 \\
\hline Hong Kong & 28855 & 20571 & 1.52 & 47.7 \\
\hline India & 3112 & 2428 & 1.32 & 43.6 \\
\hline Iran & 8375 & 14112 & 1.33 & 20.2 \\
\hline Ireland & 19460 & 39026 & 1.51 & 17.0 \\
\hline Italy & 24425 & 42252 & 1.49 & 19.7 \\
\hline Jamaica & 7250 & 16271 & 1.45 & 15.1 \\
\hline Japan & 27617 & 52980 & 1.63 & 17.7 \\
\hline Jordan & 7088 & 17426 & 1.50 & 13.8 \\
\hline Korea, Rep & 13451 & 12648 & 1.58 & 36.2 \\
\hline Malawi & 1323 & 1183 & 1.33 & 38.0 \\
\hline Malaysia & 11431 & 16025 & 1.45 & 24.3 \\
\hline Mali & 1703 & 1873 & 1.30 & 30.9 \\
\hline Mexico & 11731 & 14785 & 1.42 & 27.0 \\
\hline Morocco & 6366 & 9954 & 1.31 & 21.7 \\
\hline Netherlands & 27099 & 78859 & 1.57 & 11.7 \\
\hline New Zealand & 23822 & 58649 & 1.58 & 13.8 \\
\hline
\end{tabular}




\begin{tabular}{|l|c|c|c|c|}
\hline Niger & 2019 & 1727 & 1.30 & 39.7 \\
\hline Norway & 31529 & 80052 & 1.66 & 13.4 \\
\hline Pakistan & 3998 & 1922 & 1.30 & 70.7 \\
\hline Panama & 9998 & 19188 & 1.44 & 17.7 \\
\hline Paraguay & 8981 & 5062 & 1.38 & 60.3 \\
\hline Peru & 5919 & 12531 & 1.43 & 16.1 \\
\hline Philippines & 5652 & 4933 & 1.42 & 39.0 \\
\hline Portugal & 17942 & 20457 & 1.38 & 29.8 \\
\hline Senegal & 2823 & 3600 & 1.31 & 32.6 \\
\hline Singapore & 25801 & 26910 & 1.42 & 36.2 \\
\hline Spain & 20032 & 18833 & 1.47 & 44.0 \\
\hline Sri Lanka & 4152 & 3210 & 1.30 & 10.5 \\
\hline Sweden & 28411 & 91759 & 1.64 & 16.3 \\
\hline Switzerland & 34665 & 72374 & 1.69 & 19.6 \\
\hline Syria & 3039 & 5280 & 1.38 & 43.3 \\
\hline Thailand & 7413 & 5827 & 1.40 & 18.7 \\
\hline Togo & 1804 & 3287 & 1.30 & 22.9 \\
\hline Tunisia & 8756 & 13005 & 1.33 & 49.4 \\
\hline Turkey & 7604 & 5228 & 1.36 & 14.2 \\
\hline UK & 25680 & 61599 & 1.65 & 21.7 \\
\hline Uruguay & 11112 & 17423 & 1.44 & 12.2 \\
\hline USA & 36912 & 102630 & 1.67 & 19.7 \\
\hline Zambia & 2132 & 3672 & 1.37 & \\
\hline
\end{tabular}

